\title{
Perceptions on Implications of Delayed Marriage: A Case Study of Married Adults in Kuala Lumpur
}

\author{
Kelani Karamat
}

\begin{abstract}
It is an undeniable fact that with demographic imbalance and economic crisis among other things, the age of marriage has risen tremendously throughout the world. This study investigates perceptions of married adults in Kuala Lumpur on both positive and negative implications of delayed marriage. The sample consisted of 132 male and 130 female married staff and post-graduate students from three public Universities in Kuala Lumpur. A self-constructed questionnaire with internal consistence reliability coefficient of 0.70 was used to elicit information from respondents using a purposive sampling method. Findings in this article reveal negative perceptions on the positive implications (maturity in marital relationship, quality partner and marital stability) and no gender difference exists in the perceptions of male and female respondents on this. The study also finds positive perceptions on the negative implications of delayed marriage such as infertility, cohabitation/pre-marital sex, psychosocial effect and stress effect. It finds no difference in the perceptions of male and female on negative implications of delayed marriage such as infertility, cohabitation/pre-marital sex, psychosocial effect and stress effect. However, gender difference exists in the perceptions on the negative effect of delayed marriage on children (producing delinquent children). Negative implications are detrimental to the particular individuals and the society. By paying less attention to it, the aftermath effect may be worse than that of early marriage. In this sense, there should be a continual sensitization of people on the negative implications of delayed marriage.
\end{abstract}

Index Terms —Delayed marriage, developing countries, early marriage, implications, marriage, perceptions.

\section{INTRODUCTION}

Marriage remains an important institution which lays the foundation of a family which is the bedrock of a society. In developing countries, early marriage leads to overpopulation which has been one of the problems eroding the efforts of governments in achieving developmental goals. Overpopulation stretches to the limit the existing state infrastructures and makes lean state's coffer. Analysts and policymakers increasingly acknowledge the negative impacts of early marriage in developing countries, one of which is that, it limits women's opportunities for education and skills development [1]. In these countries, delayed marriage may be one of the solutions to overpopulation and opportunities for women participation in development.

Manuscript received December 23, 2014; revised April 30, 2015

Kelani Karamat is with the Department of Sociology \& Anthropology Kulliyyah of Islamic Revealed Knowledge and Human Sciences, International Islamic University, Malaysia (e-mail: kelanikaramat@yahoo.com).

\section{LiteratURE REVIEW}

The practice of early marriage is prevalent in developing countries like Sub-Saharan Africa and South Asia where annually millions of young girls become the wives of older men. More than 30 percent of girls are married before the age of 18 , and 14 percent before they are 15 [2]. Scholars have raised concern on early marriage because of the potential adverse consequences it has for young people's physical health, mental and well-being [3]. Early marriage threatens nearly every Millennium Development Goal; it is an obstacle to eradicating poverty, achieving universal primary education, promoting gender equality, improving maternal and child health, and reducing HIV and AIDS [4]. Also, various international agreements such as the Convention on the Elimination on All Forms of Discrimination Against Women (CEDAW) and the UN Convention on the Rights of the Child (CRC) have spelled out that early marriage infringes on the rights of women and children by denying them access to an education, good health, and freedom. Previous research found that delaying marriage has positive implications on development among which are:

\section{A. Maternal and Infant Health}

According to Hervish and Feldman-Jacobs [5] delaying marriage and childbearing can improve the health of a mother and her child. Childbirth complications are the leading cause of death for girls ages 15 to 19 in developing countries. The situation is even graver for girls under age 15, who are five times more likely to die from maternal causes [6]. In addition, girls who are married young and pressured to have children before their bodies are fully developed are at greater risk for obstetric fistula, a debilitating medical condition often caused by prolonged or obstructed labor [7]. Also, infants born to young mothers are more likely to suffer low birth weight and premature birth, and are more likely to die [8].

\section{B. HIV and AIDS}

Although child marriage is sometimes believed to be a protective mechanism, the truth is that early marriage can increase young girls' risks of HIV and AIDS and other sexually transmitted infections (STIs). Husbands of married girls are often much older than their young wives, with multiple sex partners prior to marriage, making them more likely to be HIV-positive [5]. These married girls have frequent, unprotected sex with little ability to persuade their husbands to abstain or use a condom [9].

\section{Reproductive Health and Well-Being of Women and Girls}

Increasing the age of first marriage reduces girls' risk for physical, sexual, psychological, and economic abuse. 
Delaying marriage can also increase girls' and women's decision making power and improve their reproductive health [5]. A study in India found that young women who married at age 18 or older were more likely than those married before age 18 to have been involved in planning their marriage ( 27 percent versus 10 percent, respectively); to reject wife beating (47 percent versus 36 percent, respectively); to have used contraceptives to delay their first pregnancy (11 percent versus 3 percent, respectively); and to have had their first birth in a health facility (70 percent versus 45 percent, respectively) [10].

\section{Education and Economic Opportunities}

According to Hervish and Feldman-Jacobs [5] keeping girls in school and delaying marriage can increase income for individuals and boost economic development for nations. $\mathrm{He}$ mentioned further that when girls stay in school, communities and families reap health benefits, such as decreased risk of HIV and reduced infant mortality [11].

\section{E. Delayed Marriage and Marital Stability}

Martins [12] submitted that people who delay marriage have ample time to select marriage partner of their choice thereby leading to a stable matrimony. He mentioned further that people who spend more years of their adult lives as singles before marriage show more maturity in their marital relationships due to their quality of patience, experience, calmness under stress, and willingness to cooperate which lead to marital stability in marriage. Other research also reported positive relationship between age at first marriage and marital stability [13].

Negative implications of delayed marriage have been reported in many literature. The next paragraph discusses some of these negative implications.

\section{F. Delayed Marriage and Declining Birth Rate}

Delayed marriage has negative implications on a society and on individuals in particular. The most important negative implication of delayed marriage is delayed childbearing which consequently affects the population growth. According to a report from the Social Issues Research Centre, United Kingdom [14], more have been practicing delayed marriage until their late twenties or early thirties and consequently it has shown direct impact on having children and later has brought about having fewer children. This, in effect, has catalyzed an aging population and population decline in both developed and developing societies since the beginning of the twenty-first century. Aging has become a global phenomenon as a result of increasing longevity and declining fertility, due to better diets, improvement in medical facilities, and awareness of healthy lifestyles [15].

According to a study published in Human Reproduction, a woman's fertility starts declining as early as her late 20 s and not in her 30s as was previously thought [16]. The average age for all births also rose from 26.6 in 1971 to 28.9 in 2004 and it was still just under 29 years in 2009 [17]. As women increasingly delay marriage, this automatically reduces their fertile years and attempts at conception may become difficult, thus making it likely that they will have fewer children or become infertile [18].

Childbearing rate is declining worldwide and this is evident in declining total fertility rate (TFR). The report of the World Family Map Project [19] on TFR around the regions of the world says that, Europe and Asia continents have below replacement level TFR (less than 2.1). Oceania, North America and South America have low TFR close to replacement level (2.1). Middle East has a moderate TFR (3.1) and high in Sub-Saharan Africa (5.5). Zarinah Mahari [20] states that, fertility decline would have an impact on the reduction of young people that are foreseen as an investment in the future human capital.

Globally, infertility has been estimated to affect roughly 80 million adults of reproductive age and studies show that the rate of infertility is particularly severe in developing countries, especially Northern and Sub-Saharan Africa, South Asia and Latin America, in large part due to inadequately treated sexually transmitted infections [21].

\section{G. Delayed Marriage and Abnormality in Children}

Another consequence of delaying marriage is having children later in life and this has been linked with various problems such as giving birth to babies with Down syndrome, sperm losing its vigour which can lead to many abnormalities in children as well as decline in fertility. A large scale study in Israel found that the children of men who were of 40 years or older were 5.75 times more likely to have an autism spectrum disorder than children of men under 30 years [22]. The American College Of Gynaecologists [23] reported that, the likelihood of having a baby with Down syndrome increases as the age of a woman increases.

Apart from this, delayed marriage may lead to a change in the sequence of sexual initiation and marriage [24] and an increase in the likelihood of young people having multiple sexual partners thereby increasing the likelihood of the spread of HIV/AIDS [25]. In addition, Jones [26] asserts that delayed marriage is associated with a longer period of singlehood among both men and women and regarded the period as extended adolescent period. According to him, the extended adolescence through delayed marriage has now become a major pre-occupation of parents, community leaders, policy makers and government. The period is problematic as Xenos [27] reported that it has brought with it the issues of dating, premarital sexual relations, unwanted pregnancies, abortions, STDs and AIDS.

\section{H. Delayed Marriage and Cohabitation}

Cohabitation is a prevalent phenomenon, on the rise in the contemporary society, which has replaced the normal marriage pattern more widespread in the West and Africa compared to Asia. Popenoe [28] puts it that "no family change has come to the fore in modern times more dramatically, and with such rapidity, as heterosexual cohabitation outside of marriage". According to Jones [29], there is a high prevalence of cohabitating relationship in Northern and Western Europe, many of which produce children. Chester as cited in Craig Chester [30], mentioned that there is a clear evidence to demonstrate that marriage patterns have changed dramatically in the post war era, for example, people tend to get married at an old age and are more likely to cohabit or have a trial marriage before they tie the knot. Studies on cohabitation of adults in their 
reproductive age of 18-49 years around the globe reveal that cohabiting relationships are more prevalent in Europe with Sweden and France having one-quarter of their adults, aged 18-49 years, cohabiting. This is followed by South America where Colombia has 39 percent of adults, aged 18-45 years in a cohabiting relationship. North America has a moderate level of cohabitation with Canada having a 19 percent of adults, aged 18-49 years, in cohabiting unions. Sub-Sahara Africa and Oceania are in-between with Australia and South Africa registering 13 percent of adults, aged 18-49 years, living in a cohabiting relationship. Cohabitation remains clearly less prevalent in Middle East and in most of Asia because of traditional mores on family life [19]. However, it is increasing in Japan and the Philippines, and other Asian countries despite the social unacceptability of such unions [29].

Studies have shown that cohabitation has effect on a society as well as on child developments. According to Almond [31] and Popeone [28] cohabiting couples are much more likely to break up than married couples. The implication of this is overwhelming for a society which has to provide financial support for the resulting lone-parent families. Furthermore, Popeone reports that cohabiting couples are likely to have higher rates of child abuse and family violence and also lower income. Hymowitz [32] find that "children born to cohabiting couples are much more likely to experience family instability, emotional problems and school failure". Dunifen and Kowaleski-Jones [33] report a decrease in math skills and an increase in delinquency among children of cohabitating couples.

\section{Delayed Marriage and Pre-marital Sex}

It is often likely that people who postpone marriage may become engaged in pre-marital sexual behaviour [34]. Recent wave of sexual revolution is a product of modernity and it has made pre-marital sex a common phenomenon among the youths. Throughout the world, most young people have had sex before they reach 19 years of age [35]. Scott [36] mentioned that, the rise in premarital sex in Africa has resulted from a sexual revolution that came with western culture.

Studies reveal that while puberty is occurring earlier in girls nowadays marriage is often delayed. In the U.S, the average age of menstruation which is one of the signs of puberty is 12 years in girls, while the age of marriage at first marriage is 26 years. The difference between the age of menarche and the age at first marriage is quite much compared to the past when it was just 2-4 year interval [37]. This phenomenon has however been linked with pre-marital sex as Alan Guttmacher Institute [38] assert that "an important consequence of prolonging the period between puberty and marriage is an increased likelihood that young women will become involved in sexual relationships before marriage. Examining the trends in pre-marital sex in United State of America, Finer [39], concluded that, premarital sex is not surprising in an era when men and women typically marry in their mid to late twenties and they are sexually active as singles for extensive periods. Pre-marital sexual behaviour carries the risk of unintended pregnancy and infection with sexually transmitted diseases (STDs).

\section{J. Delayed Marriage and the Risk of HIV/AIDS}

The risk of contracting sexually transmitted diseases and infections including HIV/AIDs is very high among never married people compared to currently married people based on the fact that they are more likely to change partners [34] Globally, HIV infects some 33 million people-half of them under the age of twenty five and the number continues to rise [40]. Females are mostly affected with the associated diseases resulting from pre-marital sex, compared to their male counterparts. This is due to the fact that females are more vulnerable to sexually transmitted diseases. Alo and Akinde [35], lamented that, the consequences of premarital sex, STDs (as well as HIV) are higher for females than for males. HIV/AIDs and other STDs are claiming several lives of youths who are the future of society; it decreases the size of workforce as it affects mainly adults in their most productive years of life (15-49 years) [41].

\section{K. Delayed Marriage and Abortion}

As marriage gets delayed to later ages, unmarried people who are involved in pre-marital sexual behaviour also carry the risk of unintended pregnancies [34]. Faced with this problem, a woman has to decide whether to have the child out of wedlock or to seek an abortion, especially when the woman involved is still pursuing education. Giving the estimates of unintended pregnancies, AGI and United Nation for Population Fund [42] claim that, unintended pregnancies will result in 30 million unplanned births, 40 million abortions, mostly, unsafe and illegal, and 10 million miscarriages. Ray in NMP [43] comments on the economic implications of unintended pregnancies that if all unintended pregnancies were prevented, the resulting savings on medical spending alone would equal more than three quarters of the federal FY 2010 appropriation for the Head Start and Early Head Start programs and would be roughly equivalent to the amount that the federal government spends each year on the Child Care and Development Fund.

Unwanted pregnancies resulting in induced abortion are rampant among the unmarried people. One study in Indonesia showed that 40 percent of village women seeking abortions were young unmarried women [44]. In Vietnam, one study found that 37 percent of pregnancies among young women in 2000 ended in abortion [45]. According to Federation of Reproductive Health Association, Malaysia [46], 38 out of every 1,000 women aged between 15-49 years old go for abortion and the rate of illegal abortion is 0.1 percent of 500 per 500,000 live births yearly. Abortion has claimed lot of lives of both married and unmarried women. According to Bankole [47], unsafe abortion is a major contributor to maternal mortality. It is estimated that 47,000 women will die as a result of unsafe abortion [42]. A study finds that more than 3,000 Nigerian women being treated in hospitals for complications from such procedures die each year [48]. In Argentina and Chile, more than one third of maternal deaths among adolescents are due to complications of unsafe abortions [49]. Unsafe abortion sometimes may lead to future secondary infertility in some women when they eventually marry, thereby causing everlasting miseries and marital breakup in many homes. Olukoya [50] reported that, women younger than 20 years old account for $38-68$ percent of patients admitted to 
hospitals for treatment of unsafe abortion complications in many developing countries. These complications include: cervical or vaginal lacerations, sepsis, hemorrhage, bowel or uterine perforation, tetanus, pelvic infections or abscesses, chronic pelvic inflammatory disease and secondary infertility [50].

When an unmarried woman with unplanned pregnancy chooses not to have an abortion, the decision on having the child out-of wedlock is resolved to. There has been an increase in children born outside of marriage in the recent time. In the past and still in many societies, children born outside of marriage are stigmatized and discriminated at. For instance, in England and Wales such children were referred to as bastards and whoresons. According to a report from World Family Map Project [19], non-marital childbearing is an increasing phenomenon in Europe, Latin America and North America and Oceania. Recent data by World Family Map Project reveals that in South America, more than half of children born were to unmarried mothers, placing Colombia at the highest level of 85 percent. In many parts of Europe, data show that non-marital childbearing accounts for a third and half of all births. The case in France and Sweden is similar to South America as more than 50 percent were born outside marriage. In Oceania and North America, four out of ten children were born with Canada at the lower range of 27 percent and Mexico at the upper range 3 of 55 percent. Out of all births in the U.S, the proportion of births occurring out-of-wedlock has increased to about 48 percent [32]. World Family Map Project [19] reports that non-marital childbearing varied in Sub-Saharan Africa with Nigeria assuming the lowest rate of 6 percent and South Africa having the highest rate of 62 percent. Relatively, this phenomenon is less common in the Middle East and Asia although Philippines assumes the highest rate in Asian region.

One would assume that the proportion of births should decrease with the increasing age at first marriage but the case is the other way round. More births are occurring as people delay marriage and this is due to an increasing nonmarital childbearing. In many European countries, the average age at first birth is lower than the average age at first marriage [51]. The same phenomenon is also in existence in the U.S. It is referred to as the 'great crossover' [32].

The problem of out-of-wedlock births has caused much concern because of its implications on the children. Research posits that children born outside of marriage are much more likely to experience family instability, emotional problems [32] and are "less likely to have to have positive outcomes in many areas of life, from social behaviour to academic performance" [19]. Apart from this, birth to unmarried mothers has given rise to a particularly large rise in percentage of lone parenthood [52]. Social trend [18] claims that in 1971 , only 1 percent of households were headed by a never-married lone mother, but by 2007, this had risen to 10 percent.

Limited research are available in developing societies regarding the demographic and familial change that has transformed population profiles in developed societies. This paper therefore attempts to address this deficiency by investigating the perceptions of married people in Kuala
Lumpur on both positive and negative implications of delayed marriage.

\section{MATERIAL AND METHODS}

\section{A. Participants and Sampling Procedures}

A total of 262 male and female, currently married staff and post-graduate students of three public Universities in Kuala Lumpur, namely; International Islamic University Malaysia, Universiti Malaya and Universiti Kebangsaan Malaysia were selected using purposive sampling method. Details of marital status and e-mail addresses of staff were got from various departments in the Universities. While those of the post-graduate students were got from the centres responsible for the affairs of post-graduate students in the three Universities. Respondents age range from 25-50 years. Majority of the respondents ( 88 percent) did not marry late (they married before age 30 ) while the remaining 12 percent married late (above 30 years).

Instrument: A self-constructed questionnaire with a reliability estimate based on internal consistency of Cronbach's alpha 0.70 was used to elicit information from respondents. The instrument consists of two sections; section one comprises the demographic information of the respondents and section two comprises the items that measure both positive and negative implications of delayed marriage. These sub-section place participants on a response categories of a Likert-type format ranging from $1=$ (strongly disagree) to $4=$ (strongly agree). The response options were placed from lowest to highest, or left to right in brain compatible order. A copy of the questionnaire was electronically sent to each participant.

Data Analysis: Data collected were analysed using SPSS version 20. Percentages, Mean scores and standard deviations were derived from the analysis. T-test analysis was also carried to find gender difference in the perceptions of male and female on implications of delayed marriage. Mean score below 2.5 is regarded as unfavourable of or disagree with the statements on the instrument and mean score above 2.5 is regarded as favourable of or agree with the statements on the instrument.

Results: Demographic information of respondents reveal that $72 \%$ of them were married by age $25,16 \%$ were married by age 30 and the remaining $15 \%$ married above 30 years.

Upon examining the mean of each item Table I, namely, delayed marriage ensures marital stability $(M=2.17)$, enables a quality partner $(M=2.15)$, allow people to show more maturity in marriage $(M=2.44)$, the result indicates that the respondents are not favourably disposed towards the positive implications of delayed marriage.

On the negative implications of delayed marriage, the respondents agree that delayed marriage may cause individual to experience infertility (2.76), has negative effect on children (producing delinquent children) $(M=2.50)$, and may lead to a stressful life $(M=2.54)$. The respondents however, disagree that people who delay marriage be involved in cohabitation/pre-marital sex $(M=1.99)$ and they do not agree on the view that delayed marriage may bring disrespect/shame to unmarried persons. 
Table II-2.1 reveals that no statistically significant mean difference exists in perception on delayed marriage and marital stability; $t(253)=-0.67, p>.05$ between male $(M=2.14$, $S D=0.77)$ and female $(M=2.20, S D=0.62)$. Both male and female respondents disagree that delayed marriage can lead to marital stability. Thus, the null hypothesis is retained.

Table II-2.2 reveals that no statistically significant mean difference exists in perception on delayed marriage and quality partner; $t(254)=-.69, p>.05$ between male $(M=2.19$, $S D=0.85)$ and female $(M=2.12, S D=0.69)$. Both male and female disagree that delayed marriage enables people to marry quality partner. The null hypothesis is retained here since there is no difference in their perceptions.

Table II-2.3 reveals that no statistically significant mean difference exists in perception on delayed marriage and maturity; $t(254)=-.55, \quad p>.05$ between male $(M=2.41$, $S D=0.76)$ and female $(M=2.46, \mathrm{SD}=0.79)$. Both male and female disagree that delayed marriage enables people to show maturity in their marriage. In this regard, the null hypothesis is retained.

Table II-2.4 reveals that no statistically significant mean difference exists in perception on delayed marriage and cohabitation/pre-marital sex; $t(254)=1.05, p>.05$ between male $(M=2.03, S D=0.57)$ and female $(M=1.95, \mathrm{SD}=0.65)$. Both male and female disagree that people who delay marriage may be involved in cohabitation and pre-marital sex. The null hypothesis is therefore retained.

Table II-2.5 reveals that no statistically significant mean difference exists in perception on delayed marriage and infertility; $t(254)=1.05, p>.05$ between male $(M=2.80$, $S D=0.62)$ and female $(M=2.72, \mathrm{SD}=0.61)$. Both male and female agree that delayed marriage can cause infertility in individual. The null hypothesis is therefore retained.

Table II-2.6 reveals that a statistically significant mean difference exists in perception on delayed marriage and its effect on children, $t(257)=2.94, \quad p<.05$ between male $(M=2.59, S D=0.58)$ and female $(M=2.36, S D=0.70)$. Here, the null hypothesis is rejected.

Table II-2.7 reveals that no statistically significant mean difference exists in perception on delayed marriage and its psycho-social effect; $t(256)=3.03, p>.05$ between male $(M=2.38, S D=0.78)$ and female $(M=2.07, S D=0.83)$. Both male and female respondents disagree that delayed marriage may cause individual to experience shame and disrespect. Thus, the null hypothesis is retained.

TABLE I: PERCEPTION OF MARRIED ADULTS ON IMPLICATIONS OF DELAYED MARRIAGE

\begin{tabular}{lccc}
\hline Married Adult Perception & N & Mean & $\begin{array}{c}\text { Std. } \\
\text { Dev }\end{array}$ \\
\hline Delayed marriage and marital stability. & 255 & 2.17 & .698 \\
Delayed marriage and quality partner. & 256 & 2.15 & .780 \\
Delayed marriage and maturity in marriage. & 256 & 2.44 & .780 \\
Delayed marriage and cohabitation/pre-marital & 256 & 1.99 & .617 \\
sex. & 256 & 2.76 & .620 \\
Delayed marriage and infertility. & 259 & 2.47 & .656 \\
Delayed marriage and delinquent children. & 258 & 2.22 & .815 \\
Delayed marriage and disrespect/shame. & 255 & 2.54 & .872 \\
Delayed marriage and stress. & & & \\
\hline
\end{tabular}

Table II-2.8 reveals that no statistically significant mean difference exists in perception on delayed marriage and stress $t(253)=0.74, p>.05$ between male $(M=2.58, S D=0.90)$ and female $(M=2.50, S D=0.85)$. Both male and female agree that delayed marriage can lead individuals to lead a stressful life. Thus the null hypothesis is retained here.

TABLE II: T-TEST ANALYSIS OF DIFFERENCE IN PERCEPTIONS BETWEEN MALE AND FEMALE ON BOTH POSITIVE AND NEGATIVE IMPLICATIONS OF

\begin{tabular}{|c|c|c|c|c|c|c|}
\hline & Married Adults' Perception & M & SD & T-val & Df & C-val \\
\hline \multirow[t]{3}{*}{2.1} & $\begin{array}{l}\text { Delayed marriage and marital } \\
\text { stability }\end{array}$ & & & & & \\
\hline & Male & 2.14 & 0.77 & -.67 & 253 & 0.50 \\
\hline & Female & 2.20 & 0.62 & & & \\
\hline \multirow[t]{3}{*}{2.2} & $\begin{array}{l}\text { Delayed marriage and quality } \\
\text { partner }\end{array}$ & & & -.69 & 254 & 0.48 \\
\hline & Male & 2.19 & 0.85 & & & \\
\hline & Female & 2.12 & 0.69 & & & \\
\hline \multirow[t]{3}{*}{2.3} & Delayed marriage and maturity & & & & & \\
\hline & Male & & & -.55 & 254 & 0.58 \\
\hline & Female & $\begin{array}{l}2.41 \\
2.46\end{array}$ & $\begin{array}{l}0.76 \\
0.79\end{array}$ & & & \\
\hline \multirow[t]{3}{*}{2.4} & $\begin{array}{l}\text { Delayed marriage and } \\
\text { cohabitation/ pre-marital sex }\end{array}$ & & & 1.05 & 254 & 0.29 \\
\hline & Male & 2.03 & 0.58 & & & \\
\hline & Female & 1.95 & 0.65 & & & \\
\hline \multirow[t]{3}{*}{2.5} & $\begin{array}{l}\text { Delayed marriage and } \\
\text { infertility }\end{array}$ & & & 1.05 & 254 & 0.29 \\
\hline & Male & 2.81 & 0.62 & & & \\
\hline & Female & 2.73 & 0.61 & & & \\
\hline \multirow[t]{2}{*}{2.6} & $\begin{array}{l}\text { Delayed marriage } \\
\text { and delinquent children }\end{array}$ & & & 2.94 & 257 & 0.00 \\
\hline & $\begin{array}{l}\text { Male } \\
\text { Female }\end{array}$ & $\begin{array}{l}2.59 \\
2.36\end{array}$ & $\begin{array}{l}0.58 \\
0.70\end{array}$ & & & \\
\hline \multirow[t]{2}{*}{2.7} & $\begin{array}{l}\text { Delayed marriage } \\
\text { and delinquent children }\end{array}$ & & & 0.03 & 256 & 0.32 \\
\hline & $\begin{array}{l}\text { Male } \\
\text { Female }\end{array}$ & $\begin{array}{l}2.38 \\
2.07\end{array}$ & $\begin{array}{l}0.78 \\
0.83\end{array}$ & & & \\
\hline \multirow[t]{3}{*}{2.8} & Delayed marriage and stress & & & 0.74 & 253 & 0.46 \\
\hline & Male & 2.58 & 0.90 & & & \\
\hline & Female & 250 & 0.95 & & & \\
\hline
\end{tabular}

\section{DISCUSSION AND CONCLUSION}

According to the results, both male and female respondents do not agree that delayed marriage enables people to marry a quality partner, ensures marital stability and brings about more maturity in marital relationship. To them, maturity is not associated with age and it is not certain that a person who marries after 30 years would display much more marital maturity than a person who marries earlier. Marital maturity should ensure marital stability, ceteris paribus, but in reality it is rarely so as other factors (such as low quality partner) affecting marital stability may predominate. This view is supported by previous research by Lehre and Chen [53] as well as Becker, Landes, and Michael [54] which found that women who delay marriage until after age 30 years old make unconventional matches generally associated with high marital instability due to what they refer to as a "poor-match effect" emerging with the increasing chances of infertility.

Furthermore, the results show that both male and female respondents agree that delayed marriage could cause people who delay marriage to experience infertility problem. This is due to the fact that the chance of becoming pregnant reduces as one approach older age. Previous study on the consequences of aging on reproduction reports that people who delay marriage are likely to face fertility problems because fecundity sharply declines in the 30s, making it increasingly difficult for women to become pregnant and have healthy children as they approach 40 years [55].

There is a differing perception on effect of delayed marriage on children such as late childbearing which leads to producing maladjusted children. The male respondents agree that delayed marriage could lead to producing 
maladjusted children due to the fact that parents may not be able to engage with their children effectively well due to aging and engagement with livelihood thereby making it difficult for them to socialize with their children well and mould their characters. This finding is in consonance with Morris [56] who reported that delayed marriage leading to delayed childbearing may result in negative outcomes such as less energy to train children, emotional distance between parents and children and non-normativeness. However, the female respondents disagree on this. They are of the view that late marriage would not make parents socialize less with their children and thus, children of delayed marriage would not become delinquents based solely on this factor. To them, parents who have children late would have more maturity in coping with the task of socializing with their children. This view is similar to the study of Martins [15] which reported a positive effect of delayed marriage and childbearing on parent-child relationships, particularly in early childhood when parents need more maturity to cope with the new stresses.

Male and female respondents disagree that people who delay marriage be involved in cohabitation and pre-marital sex. This finding is in contrast with the survey of people in 14 European nations which found that positive attitude was expressed toward the increasing number of unmarried couples [57]. Also, they disagree that delayed marriage may bring shame and disrespect to people. They perceive that unmarried people in their 30 s and 40 s may be seen as nonconformists to societal norms and values, but which does not necessary mean disrespect, shame and stigma on them. This finding contradicts Hymowitz et al., [32] who gave report on the well-being of unmarried people that they have higher rates of depression and lower satisfaction of life compared to married people.

In addition, male and female respondents agree that delayed marriage can lead people to live stressful lives. To them, people who marry late may not find it easy to discharge the obligations of caring for their children and elderly parents while participating in labour force. Consequently, they become physically and emotional stressed. This in line with Bianchi [58] who found that delayed marriage and childbearing are leading to increased stress for people balancing work and obligations. A similar finding was also reported by Norzareen and Nobaya [15] that women who marry late may find themselves caught between the responsibilities of caring for children and older relatives (parents) and this can be very stressful.

With so much emphasis on early marriage in developing nations, much awareness campaign is given to people about positive implications of delayed marriage. However, a little attention is given to negative implications of delayed marriage. These negative implications are detrimental to the particular individuals and its overwhelming effect on the society at large cannot be overemphasised. By paying less attention to negative implications of delayed marriage, the result may be worse than the one from early marriage. Nation's resources can be used for developmental projects and programmes for the betterment of the masses rather than bringing the resources to bear on taking care of the aftermath effects of delayed marriage. In this sense, there should be a continual sensitization of people on the negative implications of delayed marriage. Marriage education designed to give a balanced view on marriage and its appropriate timing should be incorporated in the high school curriculum so that young people can be aware of the scourge of delayed marriage.

\section{REFERENCES}

[1] S. A. Cohen. (2004). Delayed marriage and abstinence-until marriage: On a collision course. The Guttmacher Report on Public Policy. [Online]. 7(2). Available: https://www.guttmacher.org/pubs/tgr/07/2/gr070201.htm

[2] J. Walker. (2013). Mapping early marriage in West Africa. A study submitted to Ford Foundation, West Africa Office. [Online] Available: content/uploads/2013/10/Ford-Foundation-CM-WestAfrica2013_09.pdf

[3] N. Ferdousi, "Children silent victims in child marriage in Bangladesh significance of legal protection for their wellbeing," Developing Country Studies, vol. 3, no. 14 pp. 18-26, 2013.

[4] International planned parenthood federation (IPPF) and the forum on marriage and the rights of women and girls. Ending Child Marriage: A Guide for Global Policy Action. [Online]. Available: http://www.unfpa.org/sites/default/files/pubpdf/endchildmarriage.pdf

[5] A. Hervish and F. Charlotte. (2011). Who speaks for me? Ending child marriage. Population Reference Bureau. [Online]. Available: http://www.prb.org/pdf11/ending-child-marriage.pdf

[6] UNFPA. (2010). Fact sheet: Motherhood and human rights. [Online] Available: http://www.unfpa.org/public/site/global/lang/en/pid/3851

[7] International Center for Research on Women (ICRW). (2007). How to end child marriage. [Online]. Available: http://www.icrw.org/publications/how-end-child-marriage

[8] Population Council. (2004). [Online]. Available: http://www.prb.org/pdf11/ending-child-marriage.pdf

[9] C. Shelley, "Early marriage and HIV risk in sub-Saharan Africa," Studies in Family Planning, vol. 35, no. 3, pp. 149-60, 2004.

[10] K. G Santhya, U. Ram, R. Acharya, S. J. Jejeebhoy, F. Ram, and A. Singh, "Associations between early marriage and young women's marital and reproductive health outcomes: Evidence from India," International Perspectives on Sexual and Reproductive Health, vol. 36, no. 3, pp. 132-139, 2010.

[11] M. Verveer. (2010). Targeting girls in the name of tradition: Child marriage. [Online]. Available: http:www.state.gov/s/gwi/rls/rem/2010/144989.htm

[12] S. P. Martin. (2002). Delayed marriage and childbearing: implications and measurement of diverging trends in family timing. [Online]. Available: http://www.russellsage.org/sites/all/files/u4/Martin.pdf

[13] R. K. Raley and L. L. Bumpass, "The topography of the divorce plateau: Levels and trends in union stability in the united states after 1980," Demographic research, vol. 8, pp. 245-259, 2003.

[14] Social issues research Centre. (2009). Young People and Financial Independence. [Online]. Available: http://www.sirc.org/publik/financial_independence.pdf

[15] M. Norzareen and A. Nobaya, "Women of the sandwich generation in Malaysia," European Journal of Social Sciences, vol. 13, no. 2, pp.171-78, 2010.

[16] D. B. Dunson, B. Colombo, and D. D. Baird, "Changes with age in the level and duration of fertility in the menstrual cycle," Human Reproduction, vol. 17, no. 5, pp. 1399-1403, 2002.

[17] Social Trends, Office for National Statistics, 2011, London.

[18] M. Haralambos and M. Holborn, Sociology Theme and Perspectives $8^{\text {th }}$ ed., London: Collins, 2013.

[19] World Family Map Project. (2013). Mapping family change and child well-being outcome. [Online]. Available: http://www.imfcanada.org/sites/default/files/monthly_release/World_ Family_Map_2013-Final.pdf

[20] Z. Mahari, "Demographic transitions in Malaysia: The changing roles of women," in Proc. the 15th Conference of Commonwealth Statistician, New Delhi, India, 2011.

[21] R. D. Nachtigall, "International disparities in access to infertility services," Fertil. Steril, vol. 85, no. 4, pp. 871-875, 2006.

[22] A. Reichenberg, R. Gross, M. Weiser et al., "Advancing paternal age and altruism," Arch. Gen. Psychiatry, vol. 63, no. 9, pp. 1026-1032, 2006.

[23] American College of Obstetricians and Gynaecologists (ACOG), Your Pregnancy and Birth, $4^{\text {th }}$ ed., Washington, DC: Author, 2005.

[24] Blanc and Way, "Sexual behaviour and contraceptive knowledge and use among adolescents in developing countries," Studies in Family Planning, vol. 29, pp. 106-111, 1985. 
[25] D. Meekers and M. Klein, "Determinant of condom use among young people in urban Cameroon," Studies in Family Planning, vol. 33, no. 4, pp. 335-346, 2002.

[26] G. Jones, "The "flight from marriage, in east and south-east Asia," Journal of Comparative Family Studies, vol. 36, no. 1, 2005.

[27] P. Xenos, "Extended adolescence and the sexuality of Asian youth: Observations on research and policy," Population Series, Honolulu: East-West center reprints, no. 292, 2005.

[28] D. Popenoe, "Cohabitation, marriage, and child wellbeing: A crossnational perspectives," National Marriage Project, New Jersey, 2008.

[29] G. Jones, "Fertility decline: The role of marriage change in PacificAsia," Population and Development Review, vol. 33, no. 3, 2007.

[30] C. Chester. (2009). The diversity of contemporary family and household. [Online]. Available: http://www.Onlineclassroom.tv/files/posts/pdf

[31] B. Almond, The Fragmenting Family, Buckingham: Oxford University Press, 2006.

[32] K. Hymowitz, S. Jason, W. Bradford, W. Carroll, K. Kaye, and K. Yet, "The benefits and cost of delayed marriage in America," National Marriage Project, University of Virginia, 2013.

[33] R. Dunifen and L. K. Jones, "Who's in the house? Race differences in cohabitation, single-parenthood and child development," Child Development, vol. 73, no. 4, pp. 1249-1264, 2002.

[34] Alan Guttmacher Institute. (1998). Into a new world: Young women's sexual and reproductive lives. [Online]. Available: http:// www.guttmacher. Org/pubs/new_world_engl.html

[35] O. A. Alo and I. S. Akinde, "Premarital sexual activities in an urban society of Southwest-Nigeria," Ea-Journal, vol. 2, no. 1, pp. 1-16, 2010.

[36] C. Scott, Premarital Sex: Almost Everyone is Doing it, New York: MMVI, the Associated Press, 2006.

[37] R. Dahl, Adolescent brain development: A period of vulnerabilities and opportunities. A key note address at the Psychiatry and Pediatrics. University of Pittsburgh Medical Centre. [Online]. Available: http://www.pmbcii.psy.cmu.edu/dahl/Dahl_Adolescent_brain_develo pment. pdf

[38] Alan Guttmacher Institute (AGI), Sexual Relationships and Marriage Worldwide, Women, families and the future series, New York: Author, 2005.

[39] L. B. Finer, "Trends in premarital sex in the United States, 19542003," Public Health Reports, vol. 112, no. 6, pp. 29-36, 2007.

[40] UNAIDS (The Joint United Nation Programme on HIV/AIDS). (2008). UNAIDS Report on the Global Epidemic. [Online]. Available: http://www.unaids. org/globalreport/Global_report.htm

[41] UNAIDS (The Joint United Nation Programme on HIV/AIDS). In International Labour Organization (ILO) Programme on HIV/AIDS and the World of Work. ILO: Geneva, 2003.

[42] Alan Guttmacher Institute and United Nation for Population Fund [UNFPA]. (2012). [Online]. Available: http://www.unfpa.org/webdav/site/global/shared/documents/publicati ons/2009/adding_it_up_report.pdf

[43] National Marriage Project, "The benefit and costs of delayed marriage in America," National Marriage Project, University of Virginia, 2013.

[44] K. Hardee, P. Pine and W. L. Taggart. (2003). Adolescent and youth reproductive health in the Asia and near east region. [Online]. Available:

http://www.policyproject.com/pubs/generalreport/ARH_ANE.pdf

[45] T. Khuat. (2003). Adolescent and youth reproductive health. [Online] Available:
http://www.policyproject.com/pubs/countryreports/ARH_Vietnam.pd $\mathrm{f}$

[46] Federation of Reproductive Health Association of Malaysia. [Online]. Available: http://www.frham.org.my/index.php?option+comm_contents

[47] A. Bankole, G. Sedgh, F. Okonofua, C. Imarhiagbe, R. Hussain, Rubina, and D. Wulf. (2010). Barriers to safe motherhood in Nigeria. Alan Guttmacher Institute. [Online]. Available: http:/l www.guttmacher.org/pubs/2009/05/28/MotherhoodNigeria.pdf

[48] S. K. Henshaw, I. Adewole, S. Singh, A. Bankole, B. O. Adeniran, and R. Hussain, "Severity and cost of unsafe abortion complications treated in Nigerian hospitals," International Family Planning Perspectives, vol. 34, no. 1, pp. 40-50, 2008.

[49] UN (United Nations), "World youth report 2003: The global situation of young people," New York, Department of Economic and Social Affairs, United Nations, 2004.

[50] A. A. Olukoya, A. Kaya, B. J. Ferguson, and C. Abouzahr, "Unsafe abortion in adolescents," International Journal of Gynaecology and Obstetrics, vol. 75, pp. 137-147, 2001

[51] Organization for Economic Co-operation and Development. (2011). [Online]. Available: http://www.oecd.org/els/soc/47701118.pdf

[52] G. Alan and G. Crow, Families, Households and Society, Basingstoke: Palgrave, 2001.

[53] E. Lehrer and Y. Chen, "Delayed entry into first marriage and marital stability: Further evidence on the Becker-Landes Micheal hypothesis," Demographic Research, vol. 29, no. 20, pp. 521-542, 2013.

[54] G. S. Becker, E. Landes, and T. M. Robert, "An economic analysis of marital instability," Journal of Political Economy, vol. 85, no. 6, pp. 1141-1188, 1997.

[55] C. Low. (2003). Pricing the biological clock: Reproductive capital on the US marriage market. [Online]. Available: http://www.economics.uchicago.edu/Low\%20Corrine\%20Pricing\%20 RC\%20draft\%20June\%202013.pdf

[56] M. B. Morris, Last Chance Children: Growing up with Older Parents, New York: Columbia University Press, 1988

[57] Federal Institute of Population Research cited in Poponoe, 2008.

[58] S. M. Bianchi. (2010). Family change and time allocation in American families. UCLA. [Online]. Available: http://www.workplaceflexibility.org/images/uploads/program_papers/ bianchi_family_change_and_time_allocation_in_american_families.p df

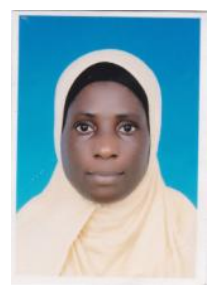

Karamat Kelani Ayotola received her B.Sc and master degrees in social work from University of Ibadan, Nigeria. She is a graduating Ph.D student at the Department of Sociology and Anthropology, International Islamic University Malaysia.

She was a social worker at the Department of Social Development, Lagos State, Nigeria. Her research interests include marriage, family, HIV/AIDs, fertility and reproductive health. She has published in European Journal of Social Sciences and Academic Research International. She has presented her work at both local and international conferences. She is a member of Nigerian Association of Social Workers. 